\title{
The Problems and Reasons of Development of Private Education in Chinese Border Areas
}

\author{
Wu Lin \\ Yunnan University Of Finance And Economics, 650221 \\ 67104250@Qq.Com.
}

\begin{abstract}
Education is a foundation of national rejuvenation and prosperity, social progress and the fundamental way to promote the comprehensive development of human. However, China is no exception, the Global challenges of Investment shortage of Education is a shortage of educational development bottleneck in most countries. Suchproblems China's border areas are even more significant. In order to solution this problem, Introducing private capital then Setting up private education is an effective way to solve the national shortage of investment in education. This paper analyzes the causes of the problems of development of private education in border areas for serving of thedevelopment of private education.
\end{abstract}

Keywords: Development of Private Education; Private Education Issue; Development and Stability of Chinese Border Areas; National Identification

\section{Introduction}

Education plays an important role in transferring knowledge, teaching skills, cultural heritage, identity formation, promoting the development of economic and human, so vigorously developing education is particularly important for any country. China's border areas, however, because of the limitation of the natural environment, the effect of slow economic development and retardation of economic society development restrict the local government investment in education, which restricts the development of education. In order to solve the shortage of government investment in education, introducing private capital, establish the private education has become an effective way to solve the shortage of education investment. More importantly, non-government funded education, which funded by private investment can overcome the defects of public education system to a certain extent, effectively the vitality of the entire education system, better meet the needs of the development of socialist market economy and people's education diversification and quality education needs. In this sense, to attract private capital investment in the western education system would not just have the value of system innovation which expanding the sources of funding education, but also has an irreplaceable strategic significance in the sustainable development education in the frontier regions, promoting the coordination development of society and education.

This paper points the problems which exist in the development of the border areas of China non-government funded education based on the statues, and tries to analyze the cause of its formation, provide help and reference for the development of education in the frontier regions.

\section{The present development Status of} Private Education In Chinese Border Areas The frontier mentioned in this article mainly refers to the borderland, which is characterized by specific boundary lines and the historical, ethnic, and cultural development differ from 
the inland, and it includes the following regions: Heilongjiang Province, Jilin Province, Liaoning Province, Inner Mongolia Autonomous Region, Gansu Province, Xinjiang Uygur Autonomous Region, Tibet Autonomous Region, Yunnan Province, Guangxi Zhuang Autonomous Region. Development of private education in these frontier provinces is also unbalanced. As a result of being located in the eastern region and being the traditional homeland of the old industrial base for the development, economic and social development in the three Northeastern provinces(Manchuria) are much better than the frontier provinces in the western region. Owing to the geographic advantages, large numbers of higher educated Han migrants migrated and developed the three Northeastern provinces in modern times, making the culture and education in this region almost indifferent from the mainland. As a result, even though the three Northeastern provinces are our country's border areas, the education development is the same as that in the mainland. However, there are great differences in educational development between the three Northeastern provinces and western border areas. Therefore this article mainly focuses on the western border regions, including Inner Mongolia Autonomous Region, Gansu Province, Xinjiang Uygur Autonomous Region, Tibet Autonomous Region, Yunnan Province, Guangxi Zhuang Autonomous Region. According to the statistics of national education in 2012, basic education situation of six provinces are illustrated in Table 1. Among these six frontier provinces, private education is more developed in Yunnan Province and Guangxi Zhuang Autonomous Region, and it has also occupied a certain share in the local education career. While the private education in Inner Mongolia Autonomous Region, Gansu Province, Xinjiang Uygur Autonomous Region, Tibet Autonomous Region are relatively underdeveloped, and the scope is small, the number of students only account for one third of that in Yunnan Province, Guangxi Province. From all kinds of non-government funded education situation In the six provinces, we can see non-government funded education involved more fields in preschool education, that is the

Table 1. Education situation of six Provinces in Chinese Western Frontier

\begin{tabular}{|c|c|c|c|c|c|c|}
\hline Province & $\begin{array}{l}\text { Popalation } \\
\text { Ten thousand } \\
\text { people) }\end{array}$ & $\begin{array}{l}\text { Expenses of State } \\
\text { finances about } \\
\text { Education } \\
\text { funding( } \Psi \text { One } \\
\text { huadred million) }\end{array}$ & $\begin{array}{l}\text { The number } \\
\text { of Public } \\
\text { schools }\end{array}$ & $\begin{array}{l}\text { The } \\
\text { number } \\
\text { of Private } \\
\text { schools }\end{array}$ & $\begin{array}{l}\text { The number of } \\
\text { students in } \\
\text { Public sctiools }\end{array}$ & $\begin{array}{l}\text { The number of } \\
\text { stadents in Private } \\
\text { schools }\end{array}$ \\
\hline nation & 130000 & 2031417 & 647724 & 139900 & 166161800 & 39110200 \\
\hline Yanian Province & 4659 & 664.07 & 27156 & 4155 & 12432969 & $990[3]$ \\
\hline $\begin{array}{l}\text { Guangxi Zluang } \\
\text { Autonomoes Reglon }\end{array}$ & 5049 & 589,78 & 16761 & 5358 & 8781663 & 1014837 \\
\hline $\begin{array}{l}\text { Mongolia Astonomots } \\
\text { Region }\end{array}$ & 2376 & 420.23 & 7875 & 2136 & 4096963 & 351767 \\
\hline Gaasu Province & 2564 & 362.18 & 18769 & 1512 & 5236425 & 335971 \\
\hline Tibet Autonomous Region & 308 & 9133 & 1599 & 13 & 584844 & 9309 \\
\hline $\begin{array}{l}\text { Xinjlang Uygur } \\
\text { Antonomous Reglon }\end{array}$ & 1846 & 462.72 & 8261 & 862 & 4407900 & 213700 \\
\hline
\end{tabular}


kindergarten, followed by primary and general junior high school which the compulsory education stage involves, then after high school education in senior middle school is the medium occupation school, the least is the higher education. See table 2 .

Table 2. The present Status of Private Education of six Provinces in Chinese western frontier

\begin{tabular}{|c|c|c|c|c|c|c|}
\hline Index & $\begin{array}{l}\text { Yunaaa } \\
\text { Proviner }\end{array}$ & $\begin{array}{l}\text { Gemext } \\
\text { Zhuang } \\
\text { Antonomoes } \\
\text { Region }\end{array}$ & $\begin{array}{l}\text { Mongolia } \\
\text { Aatomonious } \\
\text { Seeglon }\end{array}$ & $\begin{array}{l}\text { Gainau } \\
\text { Provines }\end{array}$ & $\begin{array}{l}\text { Thet } \\
\text { Antonomous } \\
\text { Etegion }\end{array}$ & $\begin{array}{l}\text { Xinjiang Oygar } \\
\text { Antonoenous } \\
\text { Fegios }\end{array}$ \\
\hline 1. The number of Private schooks & 4155 & s3s8 & 2126 & 1512 & 32 & 862 \\
\hline Regular HEI s & 20 & 21 & 10 & 6 & 0 & 8 \\
\hline Independent Institutions. & 8 & 9 & 2 & 5 & 0 & 5 \\
\hline Hrgher Vocaticoal Collegós & 12 & 12 & 8 & 1 & 0 & 3 \\
\hline Senice Secondary Edueation & 102 & 213 & 107 & 113 & 5 & 37 \\
\hline Secondary Vexational Edueation & $\$ 2$ & 131 & 75 & $\Leftrightarrow 2$ & 0 & 10 \\
\hline $\begin{array}{l}\text { Regular Servior Secondary } \\
\text { Schools: }\end{array}$ & so & 82 & 32 & 51 & 5 & 27 \\
\hline Coanpulsory eduscation & 192 & 307 & 81 & 26 & 14 & 40 \\
\hline Junicr Secondary Schools & 80 & 130 & 46 & 1) & 5 & 19 \\
\hline Primary Selocols & 112 & 177 & 35 & 9 & 9 & 21 \\
\hline Pre-school Educaticn Institutions & 3841 & 4817 & 1928 & 1367 & 13 & 777 \\
\hline Nursery & 5841 & 4817 & 1928 & 1367 & 13 & 777 \\
\hline $\begin{array}{l}\text { 2. The number of students in } \\
\text { Private schools }\end{array}$ & 993580 & 1014837 & 351767 & 335971 & 9309 & 213763 \\
\hline Regulas IIEIs & 137078 & 108135 & 19372 & 39176 & 0 & 27700 \\
\hline Incepondean Inatifutions & 90131 & & 10941 & & 0 & 19500 \\
\hline Higher Vocational Collepes & 46947 & & 8431 & & 0 & 8200 \\
\hline Seniox Socondary Education & 141577 & 179951 & $4: 971$ & $248 s 2$ & 657 & 24663 \\
\hline Socondary Voeational Education & 102920 & $12348 s$ & 31851 & 20929 & 0 & 8463 \\
\hline $\begin{array}{l}\text { Regulat Sonior Secondary } \\
\text { Schools }\end{array}$ & 38648 & $56-463$ & 13120 & 34953 & 657 & 16200 \\
\hline Contupulsory education & 131368 & 201164 & 64323 & 20622 & 5765 & 32100 \\
\hline Pre-school Education Instinticns & 52607 & 78284 & 30754 & 13359 & 1322 & 11300 \\
\hline Primary Schools & 78761 & 122880 & 33569 & 7263 & 4443 & 20800 \\
\hline Pre-school Echscation Institutions & 583557 & 525587 & 223101 & 195819 & 28887 & 129300 \\
\hline
\end{tabular}

From the perspective of the six provinces of non-government funded education geographical distribution, it mainly concentrated in the central city of each province and central city of each county. Take the distribution of Yunnan province for example. We can see from the data, nongovernment funded kindergartens are distributed in each prefectures, which are concentrated in central Yunnan, many of whom have parenting education and training classes; other non-government funded schools at all levels concentrated in the central area of Yunnan, and the distribution is not balanced. It is not difficult to see that the development of private education in border areas is from the central city unceasingly expanding along roads, the trend of its development is similar with economic and culture spread from the center to around.

From the perspective of present situation of private education in western border areas, private education has been improved in general. But this uneven development in different regions forms the different characteristics and distribution patterns. In sparsely populated areas, especially those relatively under developed 
and ethnic aggregation areas, their private education develop slowly. Private schools for the children of migrant workers and children left behind in rural area have been set up in Guangxi and Yunnan where private education has been developed rapidly. These schools charge a low tuition and focus on compulsory education. With few teachers and poor school conditions, their size are small.

Pre-school education are the primary field of private education development in western border areas. That is very similar to the constitution of national private education categories. The overall level of pre-school education in western areas is relatively low. There is a serious shortage of public kindergartens. It is difficult to meet the society's demand for pre-school education. The entry and exit barriers are generally not high. Considering the relaxed policy environment, relatively abundant teacher resources and short payback period, preschool education is the first choice of private funds especially the small-scale private investment.

Social training (non-academic education) is the main form of private education in western border cities. It is very similar to the development of private education of cities across the country. Social training consists of English language training, parenting education, tutoring, college entrance repeat, skills training, management training and so on. A large number of the training institutions register in industrial and commercial authorities and they become one of the fastest developed private educational institutions in recent years; since the different approval standards has taken in industrial and commercial sectors, labor and education sectors, false advertising phenomenon becomes more serious. So, social training institutions become the main target of complaints from the masses and the main management object of the educational administrative departments.

In the academic field of education, at the end of 2012,the number of students in nongovernment funded colleges and universities is about 41 million in border areas, , accounting for $7.6 \%$ of non-government funded colleges in the total number of students in the school, blow the proportion of the population in this area; the standards of compulsory non-government funded school fees generally not high; there are 15.9 million students in non-government funded high school, accounting for $6.8 \%$ in the total number of students in the school of our country in that year, significantly lower than the proportion of the population in western area. But non-government funded high school education in Guangxi, Guizhou, Hongkong accounted for more than $40 \%$ in the number of local ordinary high school, and has large school scale, high quality education, is a model of private education in Guangxi. Nongovernment funded education is actively encouraging in the west of China. In recent years, many western provinces, city, autonomous region government make the policy of encouraging and supporting the development of non-government funded education, then promote the development of local non-government funded education.

3. The existing problems on the development of private education in frontier regions

Although not only the state encourages and 
supports the development of private education, but local governments also have issued local policies and regulations to promote the development of private education, the development of private education in frontier regions still exists many restrictive factors, at present the main problems of affecting the development of private education in frontier regions can be summarized as follows:

\subsection{Unbalanced development in different} regions, undeveloped private education

From the current status quo of private education in western frontiers, private education developed in general, but the development between regions is unbalanced, and form the different characteristics and distribution patterns of local and provincial governments. The development of private education in those regions that have low population concentration, less-developed economy and several minorities living together is relatively slow. Private education make preschool education as the main development field, and social training as the main social morphology, and is short of high grade education.

\subsection{Mismatched policies supporting on} private education from the state

The private educational system design in frontier regions is mismatched, and policies supporting does not reach the designated position. Preferential policy is not implemented, and the policy environment has uncertainty stems. In conclusion, they all reduce the enthusiasm of private investment. How to solve the contradictory between "profit-making purpose" and "gaining reasonable benefits", and make public welfare of the school and seeking the profits of the capital find a best combining site, which is the problem for the development of the private education continuing to solve. Private Education Promotion Law explicitly stipulated: "private education is the public welfare undertakings, and a component part of socialist education", "private schools and public schools have the equal legal status", "teachers in private schools and public schools, and students in private schools and public schools have equal rights", but in the tax of private schools, benefits and social security for teachers, and the interests of the public finances for students, and other important issues is still short of reasonable supporting system and policy design, which makes private education is often confined to the fields with low cost, fast return, and fewer restrictions.

\subsection{Low -status and undeveloped private} schools

From the current situation of view, unclear relations between private schools and public schools, which make private education be in the long-term supporting position, and the development of private education is restricted. In addition, unclear relations also exist between government and private schools. And the unclear relations mainly include that some local government with too much intervention in private education development, and making private education of this region in a position of discrimination; Or with too little interference and letting it drift, which cause the disordered competition of private education.

\subsection{Low social benefit for teachers, high mobility of teachers}

Because of the high mobility of private school teachers and serious loss of many excellent teachers, optimizing teaching staff increased the difficulty. The unsteady teaching staff has 
become a big concern for private schools in frontier regions. The reasons for this include as followed: Firstly, because of the government increasing investment in public education in recent years, teachers' salaries has grown substantially, which make the wage advantage of teachers in private schools weakens continually; Secondly, because of private school has been qualified as "private non-enterprise entities", teachers in private schools enter into the enterprise pension security system, a retired teacher in private schools who enjoys the basic pension insurance is over $50 \%$ less than the retirement pension of teachers in public schools, which lead to the staying away of good teachers, and had a serious impact on the competitiveness of private schools; Thirdly, because of the state with unclear long-term development strategy for private education, which lead to unclear career prospects for teachers in private schools; In addition, the working hours and labor intensity of teachers in private schools is often higher than those in public schools, which make private schools have less attractions for teachers, especially for excellent teachers, and also seriously affect the social image and education teaching quality of private schools.

\section{The influential factors on the} development of private education in frontier regions

The influential factors on the development of private education in frontier regions are various, including internal and external issues. It is chiefly behaved in the following aspects:

\subsection{Economic development level} backwardness is the important limitation for private education in frontier regions

The cultivation and development of private education is closely connected with regional Objectively people in these areas has greatneedsocial economic development level. The western frontier area of China is such a province with frontier, ethnic groups, poverty and mountains. It has the low per capita income and large poverty; The economical development is very different between urban and rural areas, so as mountains and dams. The development of different regions is unbalanced, and the economic development of minority ethnic autonomous areas is very backward. The existence of these features hindered the development of private education in frontier regions in some ways, which makes the cultivation of frontier regions' education still in a lower stage.

The frontier regions have the backward social economic development, weak economic foundation, low living standard, large poverty, low production of private enterprises, which limit the development of private education and affect the investment level of private education in frontier regions. Therefore, the investment of western frontier education still gives the priority to financial allocation for years, but funds for running schools has no significant increase. In addition, people's economic strength is the material insurance for the development of private education. After people's daily necessities are satisfied, if they have surplus purchasing power to afford highquality education fee for themselves or their children, which will ensure the material supplies for the rise and development of private education. Therefore, those relatively good central cities of the frontier regions became the concentrated areas of private education. 
For rural residents, because of the limitations from economic and cultural infrastructure, traffic conditions and natural geographical conditions, the education requirements, education teaching quality and level are lagging behind, as well as the number of public schools is insufficient, and a large part of their children is difficult to go to the high level of public schools, so most of the students in private schools come from rural areas. for a good education, but people's poverty and relatively high tuition fees of private schools formed a pair of contradiction. Therefore, in terms of necessary levels, it is not reality that those who even the most basic food and clothing problems are still not solved have more educational needs. And it is often because of lacking of education, the development of the rural public space has the limitation in frontier regions, and people often stay in the low living standard and with weak happiness, which will cause lower territory identification, higher pursuit of economic interest, and lead to border and national crisis.

Therefore, if without the solid economic base, the educational needs of people will is just a kind of impossible desire, private education will like an air castle which made them failed to reach for.

\subsection{Lacking of recognition, limited} attention, making the status and role of private education has yet to be seen

For a long time, because our country implements the single mode of governmentrun schooling, which makes many people form a mind-set: only public schools is normal school, other running forms is just some meaningless behavior, so that private education from recovering development has been more than 20 years. But society, parents, students, and some government departments are lack of recognition and also have limited attention on the status and role of private education, and there even exist much discrimination. Obviously, the conceptual problem as an important reason is restricting the development of private education in frontier regions.

In addition, the attention and support of administrative departments of frontier regions is not enough, which is restricting the development of private education in frontier regions as well.

\subsection{Mismatched system design, lacking of policy supporting, unimplemented preferential policy, and unstable policy environment}

Private Education Promotion Law explicitly stipulated that "private education belongs to public welfare undertakings, and a component part of socialist education", and "private schools and public schools have equal legal status", and teachers in private schools or public schools, students from private schools or public schools do have the same rights". But on the issues of private schools' tax, teachers' benefits and social security, and students' financial interests, which still lack reasonable supporting system and policy design. Tax preference policy for private schools has not introduced, and exit mechanism of private schools is deficiency, asset security has no protection as well. Some school sponsors take violating standards in the period of continued existence to recoup investment, secretly withdraw funds or evade repayment of debts, which reduce the social evaluation of private schools. While the relevant regulation system is not perfect enough so that the quality of private education 
in frontier regions is relatively low, and restricts the development of private education.

In short, the development private education in frontier regions is influenced by many comprehensive factors, only seriously present their relationship, can we truly result in the healthy development of private education, which contribute to the stability and prosperity of frontier regions.

\section{References}

(1) Private Education Promotion Law of People's Republic of China. From People's Republic of China Ministry of Education Portal.

http://www.moe.gov.cn/publicfiles/business /htmlfiles/moe/moe_193/index.html

(2) Number of Non-government Education by Type and Level. From People's Republic of China Ministry of Education Portal.

(3) http://www.moe.gov.cn/publicfiles/business /htmlfiles/moe/s7567/201309/156892.html

(4) ___ (2013). 2012 Statistical Abstract of education in Yunnan. Department of Education of Yunnan, Jan,2013.

(5) Hu Young yuan ,Liu Zhi-yong. (2004). AnAnalysis of Regional Differences Between Non-government Funded Schools in China. Tsinghua Journal of education, June,2004 